\title{
CHANGE IN THE IMAGE OF REGION TOWARD THE SPATIAL SETTING AND BEHAVIOR (A case study of Tamansari "Cyber" Village, Yogyakarta)
}

\author{
Bhanu Rizfa Hakim ${ }^{1 *}$, Amos Setiadi² \\ ${ }^{1}$ Architecture Study Program, Politeknik Negeri Samarinda \\ ${ }^{2}$ Master of Architecture, Universitas Atma Jaya Yogyakarta \\ *Corresponding author; Email: bhanuhakim@polnes.ac.id
}

\begin{abstract}
Cyber village is a residential area in RT (neighborhood association) 36 in the tourist area in Tamansari Yogyakarta. It has recognized image as an information technology based region with good internet network. Internet technology at the cyber village is slowly changing the behavior of the citizens from the social, economy, culture and tourism aspects. The behavior changes on the social, economic, cultural and tourism aspects affect the spatial setting at Tamansari "cyber" village to become a unique tourist area. The methods used in this research were Qualitative Research through observation to identify phenomena that occur, interviews, and literature studies that were analyzed by behavior setting method. The results of this research showed that changes in the image of the region influence the citizens' behavior that finally creates certain spatial settings to meet the needs for space which could accommodate the village potentials, covering the social, economic, tourism and cultural potentials.
\end{abstract}

Keywords: Cyber village; information technology; behaviour; spatial setting.

\section{INTRODUCTION}

Tamansari "cyber" village in Yogyakarta is an IT based village due to the existence of internet. This village is part of Tamansari tourist destination, which in the past was functioned as part of the baths complex of the Sultan's family. Near the village, there is an underground mosque that enables tourists to pass through the village. Tamansari "cyber" village makes use of the internet to stimulate economic activities, such as opening batik kiosks, t-shirt printing, paintings, fishing rods, and graphic designs which are on sale either directly or through the internet. The village has evolved into a unique tourism destination which citizens live in harmony and communal work; although the internet makes it easy for citizens to communicate digitally, this may not necessarily cause the residents to become individualists. Tamansari "Cyber" Village adopts internet technology since 2008 in an effort to collectively empower the citizens. The effort is persistently growing until now most of the citizens have been connected and able to operate the internet from their house. Since the community is increasingly gaining its reputation, there are many guests coming to learn the success of the community (Prasetyo, 2014).

Internet's influence starts the expansion of the social, economic, education and culture potentials in the cyber village. In the social aspect, the people build social networks based on information technology to introduce the village potentials and exploit them among citizens. From the economic aspect, the residents of the "cyber" village are from middle low society, local artists, and employees. The internet allows citizens to collect information to develop the lokal potentials that could generate money for improving the economy. In terms of education, Tamansari "Cyber" village is being evolved into "socio laboratory" to accomodate school and university students and often used as subject of assignments, thesis and desertation. From the socio-culture side, the artists at Tamansari often produce artworks and sell them online through the internet. They build painting and sculpture studios in the village (Sasongko, 2016).

Tamansari "Cyber" Village has developed due to the internet that characterizes it. Residents of Tamansari "Cyber" Village are having awareness to gradually improve their neighborhood, such as by giving visual identity at the entrance of the village, establishing "Pos kamling (security post) or "cakruk" as the meeting points of the citizens and the central servers, distributing internet cable to all houses in RT 36, as well as installing IP Cam or CCTV or in some corners of the village. Citizen information system begins to grow, along with the more intense use of social networks, blogs and sms gateway.

The coming of internet in RT 36 Tamansari has made the new identity in the area as a cyber village. The internet creates a certain pattern of behavior changes of the citizens, including social, economic, 
culture and tourism behaviors. The problem formulated in this study is how changes in the image of region give impact to the behavior of the citizens in terms of social, economic, cultural and tourism aspects. These observations will hopefully provide descriptions of the citizens' behavior and spatial setting as unique supporting elements of tourism activities.

\section{MAJOR HEADING}

\section{Behaviour Setting}

Barker(1987) suggests that behavior setting is a small scale social system which components include people and materials as the objects. Within the time and space boundaries, the various components of the system interact regularly in a certain way to carry out an activity. The patterns of behaviour that appear regularly within the time and space boundaries that cause the emergence of an activity are called program setting.

According to (John, 2004) argues that "Every psychological phenomenon in humans is always associated with another phenomenon"; this is one of the conceptual thinking in psychology about the behavior. This assumption links one phenomenon to others as a meaningful whole. The other related assumptions include:

1. Every individual is residing in the ever-changing world of experience, where he becomes the centre.

2. As an organism, an individual reacts to the environment as the environment was observed and experienced firsthand. For individuals, the observed world is a fact.

3. As an organism, an individual reacts to the environment of the phenomenon as an organized whole.

4. An organization has the inclination and the great impulse for self-preservation, developing themselves and also self actualization.

5. Basically, behaviours are the attempts oriented to the goal of organisms, i.e. to satisfy their needs, namely in the environment as they live.

6. In general, emotions are involved and support the directed and purposive behavior.

7. In order to understand human behavior, it is best to understand their own internal frame of reference.

But in the case, the behavior setting aspect involves not only one phenomenon with one phenomenon. Behavior settings have many other properties, characteristics, and elements. One is a geographical locus. Another is a temporal locus, including serial occurrence and duration. Other characteristics are population (subgroups), occupancy time, penetration in the behavior settings (six degrees of penetration and corresponding positions of the participants); action patterns (with sub-elements as participation, supply, evaluation, teaching and learning); program (rules and regulations that structure the activity); behavior mechanisms (participation, tempo, intensity); affective behavior, gross motor activity, manipulation, talking, and thinking; richness; degrees of pressure (e.g., required, urged, invited, neutral, tolerated, resisted, and prohibited); welfare; local autonomy; genotype; and authority system (leadership, etc.) (Popov \& Chompalov, 2012).

According to (Lang, 1987) when talking about human interaction with their environment, humans will always strive to obtain the harmony with the environment. This is made possible by the existence of cognitive ability to hold certain reactions to the environment with certain things that attract their interests, particularly that meet their needs. Behavior settings have always been ubiquitous in human environments (Heft, Hoch, Edmunds, \& Weeks, 2014). One important fundamental construct is "standing pattern of behavior," which is an abstraction that stands for the persistent reoccurrence of a behavioral phenomenon. In order to transcend this abstractness, the construct "action pattern" is introduced. The action pattern still represents several phenomena. It is operationalized in terms of particular variables and degrees of occurrence (Popov \& Chompalov, 2012). Important features of behavior settings are categorized into three aspects: source, internal dynamics, and context (Luke, Rappaport, \& Seidman, 1991). The development of Tamansari "Cyber" Village as an internet-based village encourages the residents to always strive to improve. The settings due to the internet's influence affect many of citizens' activities, including social, economic, cultural, tourism activities.

\section{METHODOLOGY}

\section{Primary Data}

The research was using Qualitative Research techniques. Field observations are applied to collect data through observations and record the symptoms that appeared on the research object directly to the site where an event, circumstance, or a situation is happening (Nawawi, 1995). In this study, the observations were done through behavior setting. Examining the behavior setting was performed with the behavior mapping. This study employed place centered map as the behavior mapping technique. 


\section{Secondary Data}

Interview is a qualitative data collection technique using instruments, namely interview guide. The level of success in interview depends heavily on the ability of researchers to lead the interview. The data they want to reveal through interview is information on symptoms or phenomena that are not visible or are already underway before the research was done. Meanwhile, the literature study is a method used to discover or obtain data related to theories that support the research. Therefore, the literature study is very significant to complement the data on the field.

\section{RESULTS AND DISCUSSION}

\section{An Overview of the Village}

Cyber village in RT 36 has characteristics which differentiate it from other neighborhood associations, such as RT 34 \& RT 35 which are famous as Batik Villages, and RT 37 as Green City Village. Cyber village is an IT-based village accommodating the citizens to interact socially, while engaging economic, and socio-culture aspects. Actually, internet network is built to form the village identity and to make the residents more technology literate. IT-based village
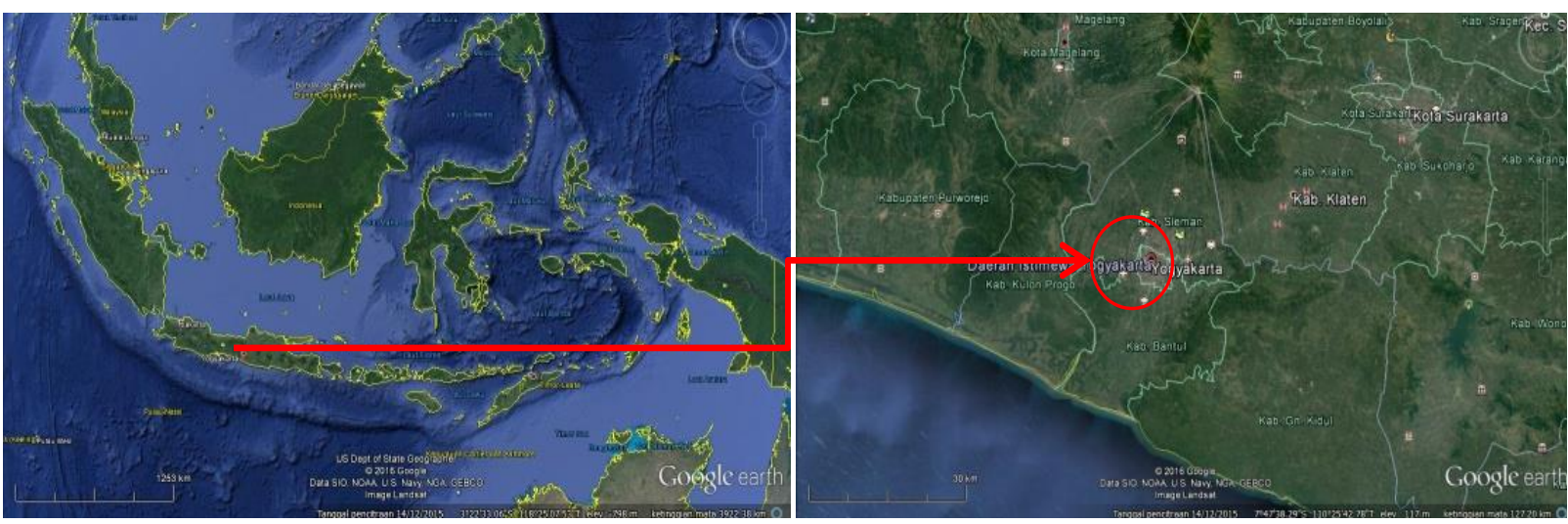

Fig. 1. Indonesia (left), and Figure 2. Yogyakarta (right). Source: (Google earth.com, 2016).

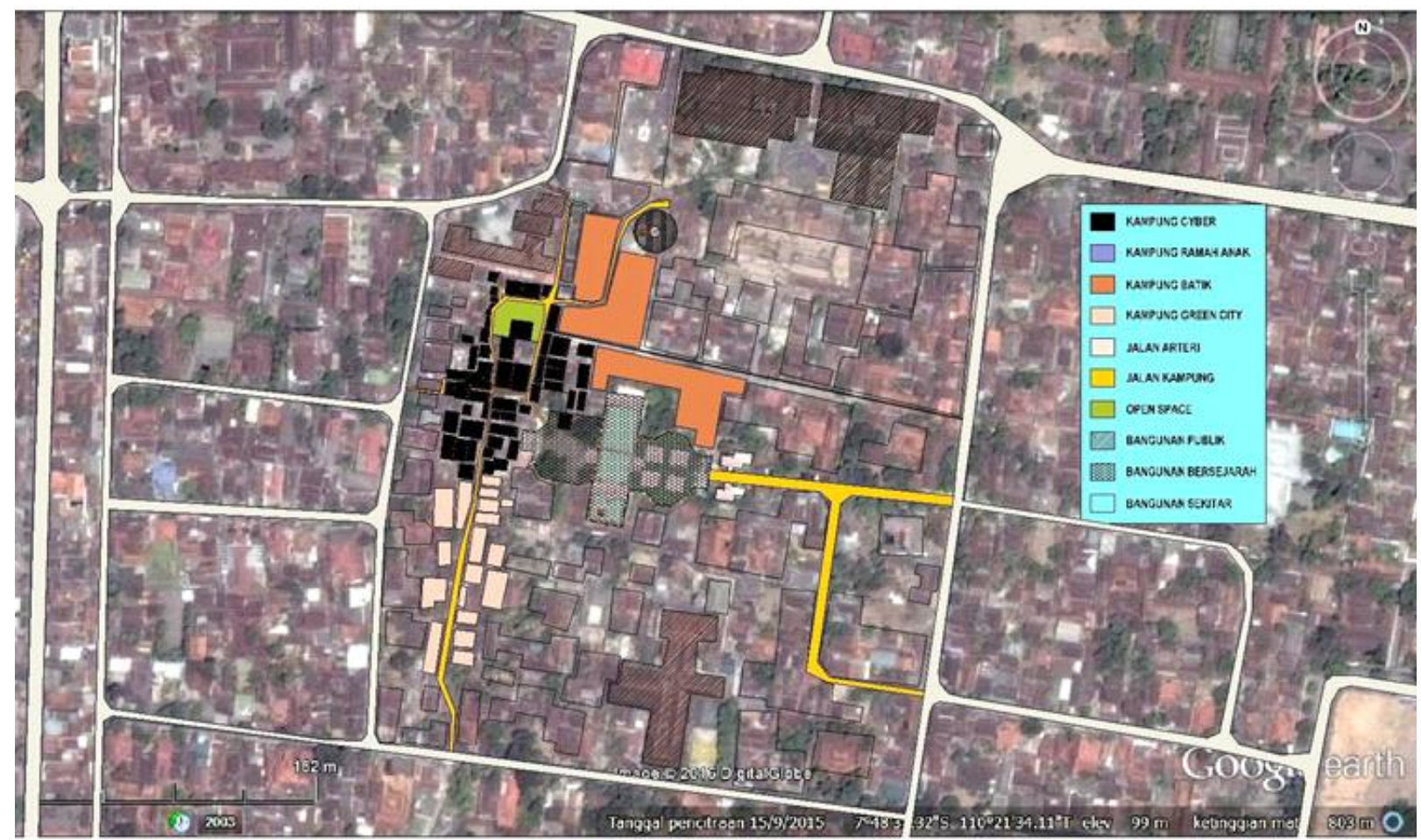

Fig. 2. The Ground Mapping of Cyber Village in the Tamansari Complex (Source: Personal Documentation, 2016) 
refers to an area connected with the internet, both through wifi, wired LAN, and IP Cam.

Cyber village is situated in the complex of Yogyakarta Palace that borders Tamansari, inluding he Queen's bath and underground mosque so that the main gate of the village is always passed by tourists. However, there is yet no special sign that points directly towards cyber village from outside of the complex. The citizens take advantage of this situation to arouse their creativity and sell their art products in stores and through online system. Unfortunately, this potential is not supported with rigorous discipline to organize the neighborhood well that makes it like villages in common.
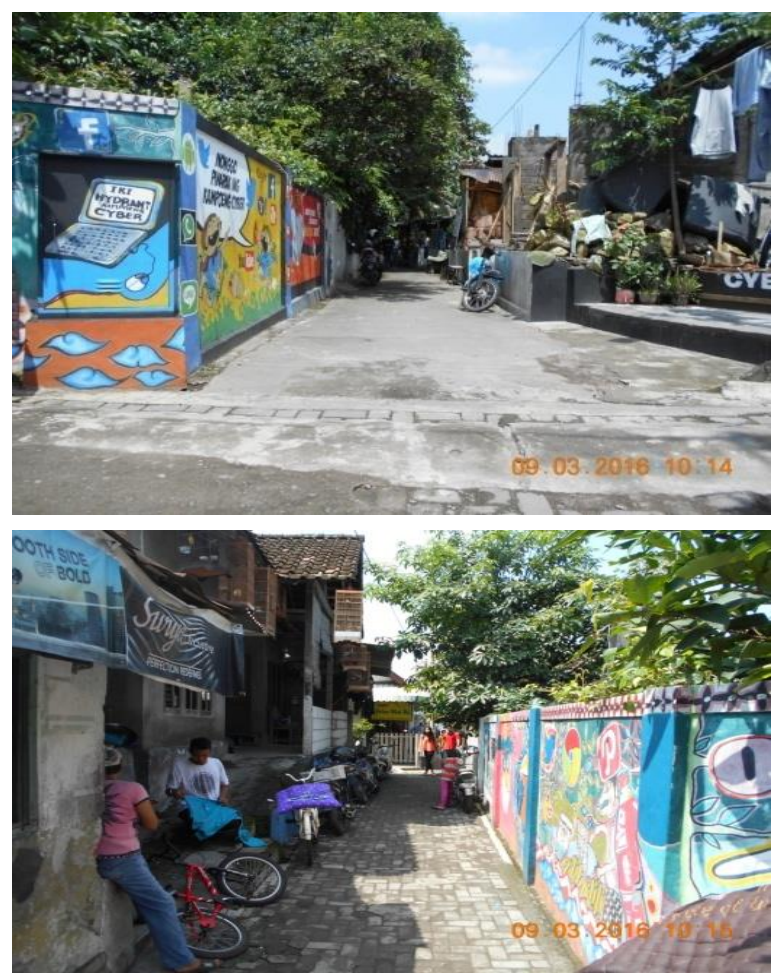

Fig. 3. The main entrance of the Cyber Village that is decorated with mural as a visual identity; Figure 3 . The path within Tamansari tourist area that pass through the Cyber Village. (Source: Pesrsonal Documentation, 2016)

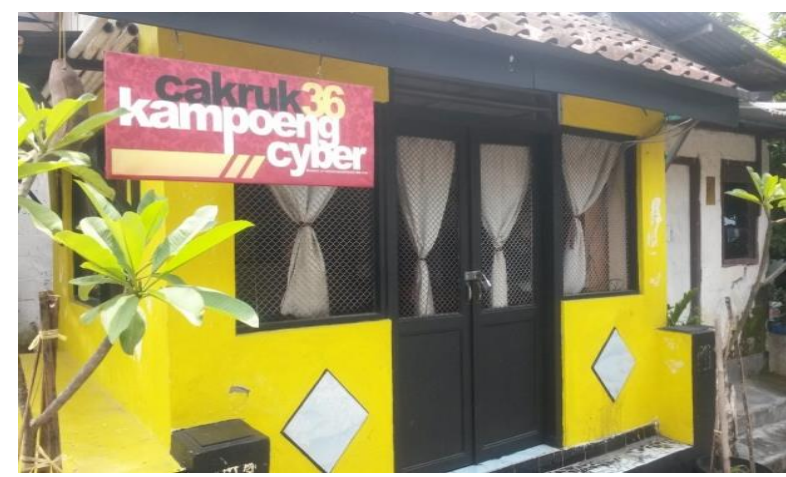

Fig. 4. Cakruk (security post) as communal space and center for servers (Source: Personal Documentation, 2016)
The potential of the village can be seen from four aspects, namely the aspects of society, economy, tourism, and culture (Sasongko, 2016). The potential of the village can be seen from four aspects, namely the aspects of society, economy, tourism, and culture (Sasongko, 2016). The social relationships among citizens are linked through information technology, through the application of SMS gateway, Facebook, and Blog. All enterprises existing in cyber village have a website to attract tourists to come to the site and also online buyers, both regional and international, to shop there. Initially, the internet was originally iniated by 12 citizens, now it has reached 49 households with 150 people. In fact, internet successfully evokes the creativity of the residents who were previously jobless but having passion in art. With the asssistance of information technology, now the residents can work together promoting cyber village while improving the economy. In the perspective of tourism, all the efforts and hard works are inspiring and could attract those from education sectors to study the development of the village. Many school and university students visit the village to gain insight and discuss about cyber village, the history, lifestyle, social interaction, and others. In terms of art and culture, the village is inhabited by a number of local artists, since the area surrounding Tamansari has long been acknowledged as the center of arts and culture. With the establishment of cyber village, the interaction is not only by direct meeting, but also via email and social media; hence, the customers can be from anywhere and the residents do not need to sell their products at the road side. (Hakim, 2016).
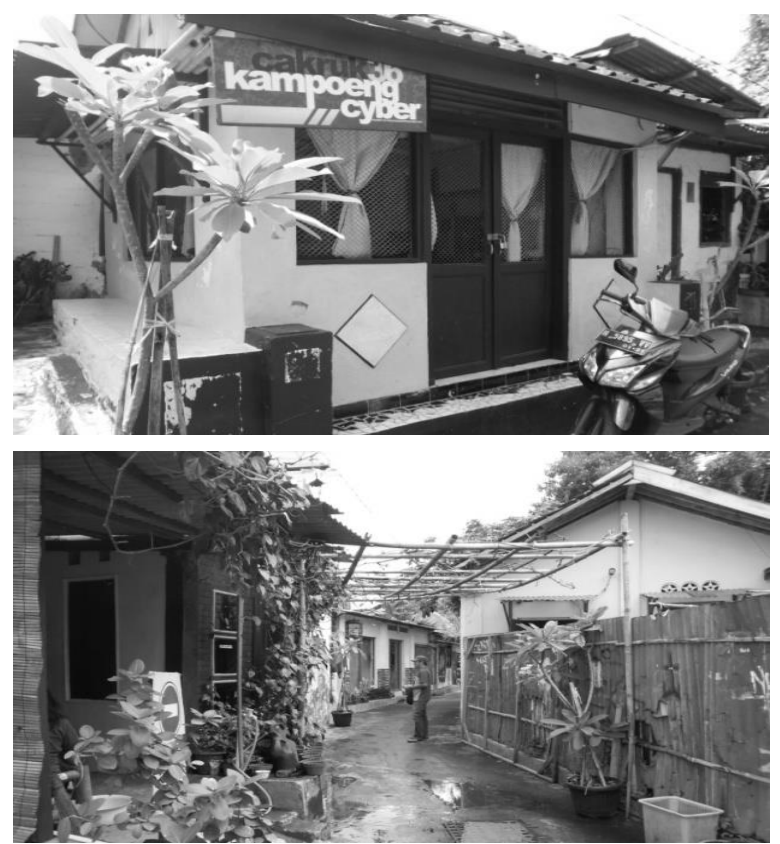

Fig. 5. Cakruk/Security post (left) of the Cyber Village; Figure 8. Spatial Setting of the neighborhood (right). Source: Personal documentation, 2016. 
The birth of "Cyber" Village in Tamansari as an internet based region gives rise to changes in behaviors; one of them is social behavior. It is understood that Tamansari "Cyber" Village has evolved into a unique tourist village which citizens still practice harmonious lifestyle and communal work. The fact that the internet facilitates the citizens to communicate digitally might not necessarily change the residents to become individualists. Moreover, the IT facility allows the residents to browse the webs at their respective house and communicate in a wireless network through interpersonal channels, thus reducing the information by word of mouth that eventually shifts the function of gathering space a bit, namely to only discuss activities which have been previously addressed through social media and the gathereing is done only once 1 month regularly (Samatan \& Sutanlo, 2013).

\section{Behavior and socio-economic activity}

Cyber village is an area in the Tamansari tourism complex that is located at RT 36, RW 06 Patehan Subdistrict, Palace District, Yogyakarta Special Region. This village emerges as a response toward the penetration of internet in the place. Previously, the area was named Taman Village (Garden Village) since it is included in Tamansari complex (Samatan \& Sutanlo, 2013). Before, it was also famous as Village Budaya (The village of culture) as it was the home for local artists, batic crafters, painters, and sculptors (Sasongko, 2016). The citizens are still practicing communal works up to now; hence, the communication among citizens is still well maintained.

Cakruk acts at the centre for public talks, where the residents gather to communicate with each other and discuss the activities to be carried out. Residents routinely conduct meetings in cakruk for exchanging ideas or just having regular meetings to maintain the relationship. The village would gladly welcome the visitors as it is close to Tamansari. This situation brings opportunity for artists to sell their works, such as a t-shirts and batik paintings, and wayang kulit (shadow puppets). In addition, there are 2 studios on the cyber village, namely a painting studio and a sculptor studio. Those are busy and bustling with people, particularly kids who want to learn in the studios.

\section{Behavior and Cultural - Tourism Activities}

Tamansari is well known as Garden Village (Kampung Taman) or Culture Village since it is inhabited by many batik craftsmen, painters, and sculptors.
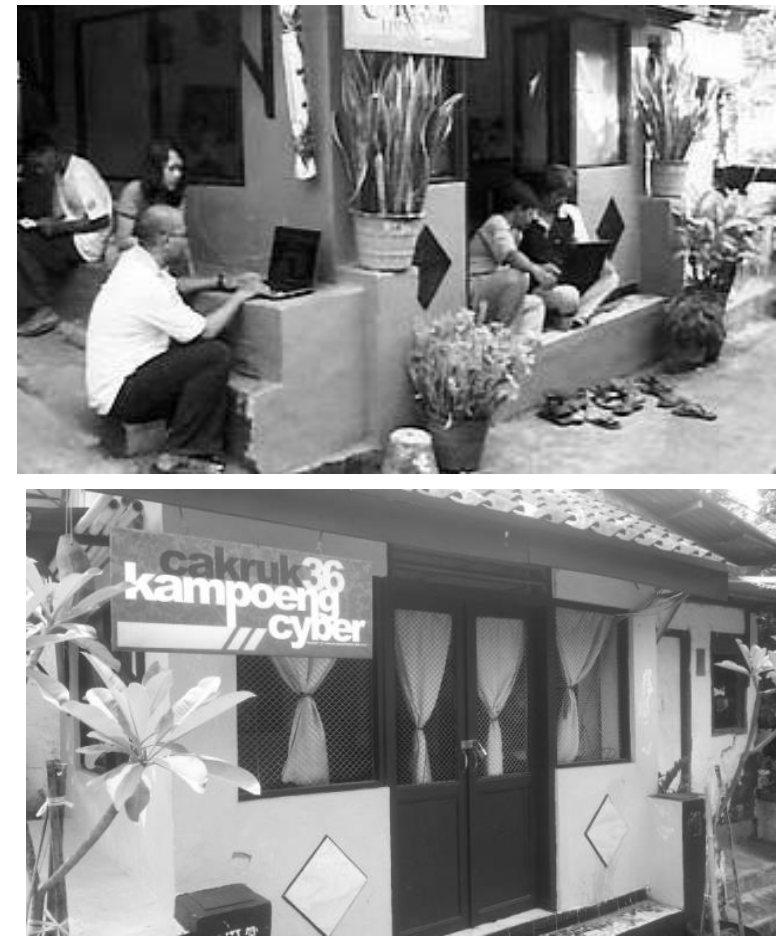

Fig. 6. Cakruk as communal space in Cyber Village.

Source: www.rt36Kampoengcyber.com; accessed on 13/10/2016; 13.45)
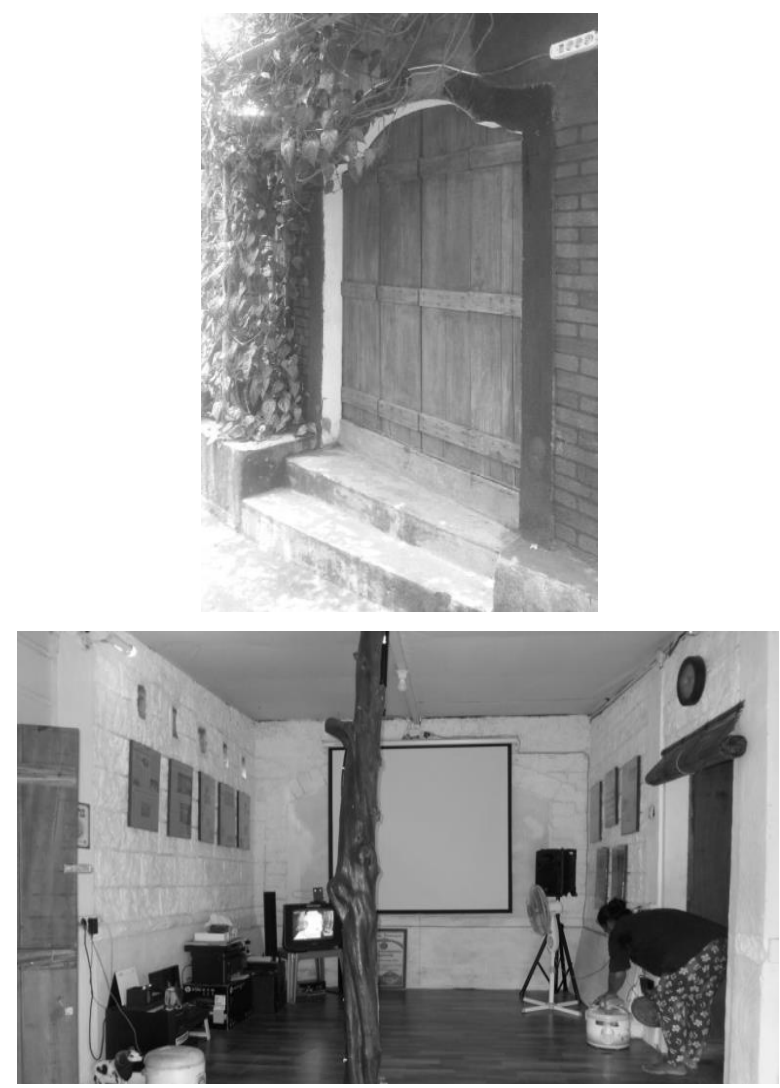

Fig. 7. One of residentials utilized as meeting space between residents and a small number of tourists in (Source: Personal documentation; accessed on 9/3/2016; 10.30) 


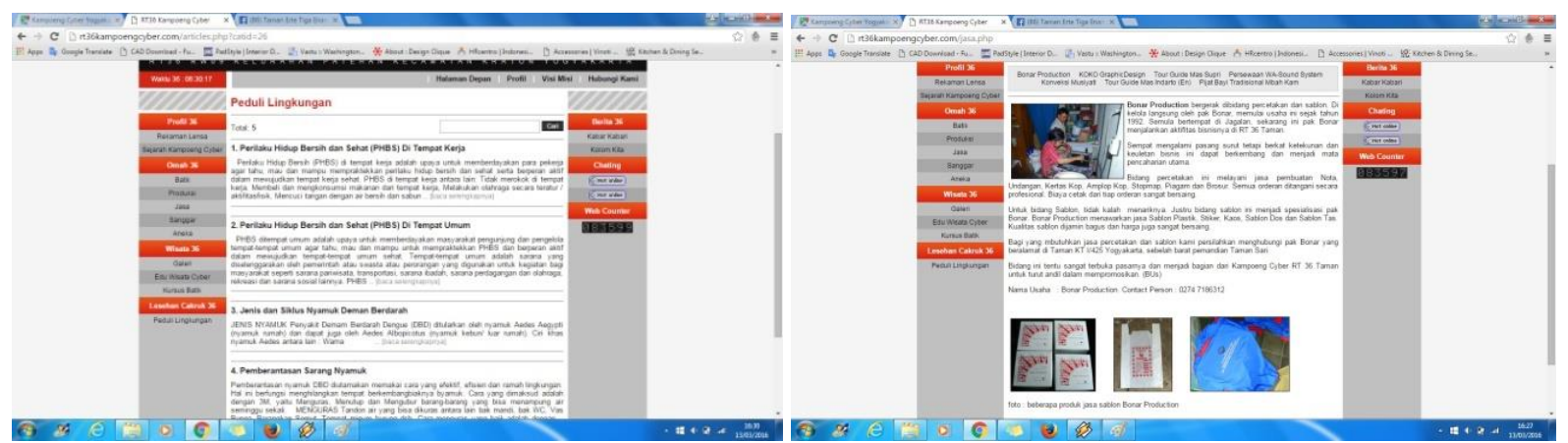

Fig. 8. The website of Cyber Village as a socialization media to introduce business potentials (crafts). (Source: www.rt36Kampoengcyber.com; accessed on 13/10/2016; 13.45)

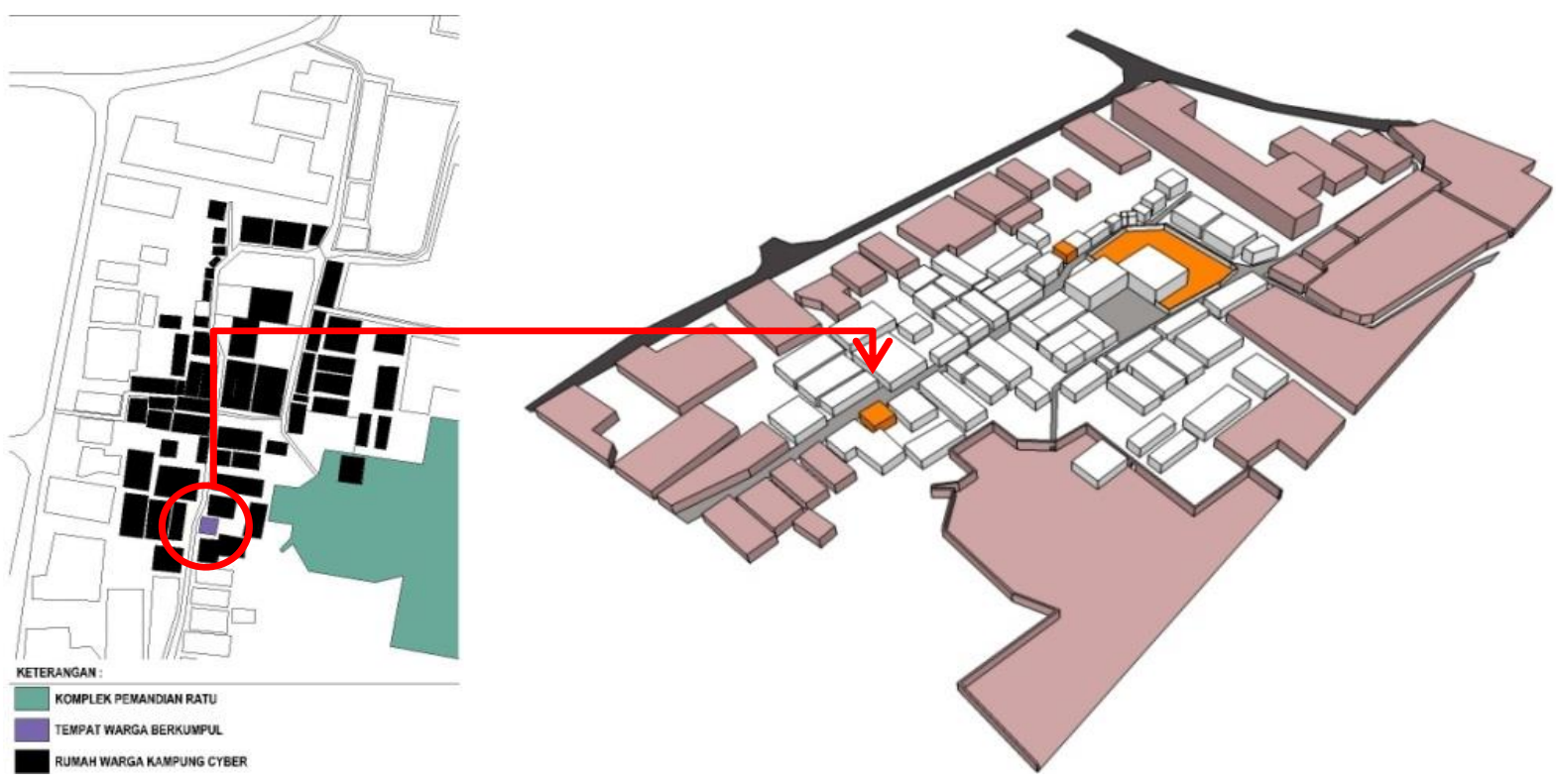

Fig. 9. The map showing the location of cakruk as a main server room; (left); Figure 4. The current condition of cakruk in the Cyber Village (Source: Pesonal Documentation; 9/3/2016; 10.30).

Before the penetration of the internet, the village was simply a small alley that linked Queen's bathing pool and Gemuling Well. Today, the batik craftsmen, painters, and sculptors create products on regular basis and then sell them in the nearest market. The alley where the tourist pass by is having huge potentials for improving the economy. It also helps introduce the new identifty of the village, as a cyber village. At the end, along the alley, there are many kiosks selling batik, painted t-shirt, and also some rest areas.

The transformation of RT. 36 into a cyber village was initiated by Anthony Sasongko who later gained support from other citizens. The penetration of the internet in this village was done gradually because many citizens of RT 36 at that time was not aware of the function of the internet. However, after conducting several trainings on the use of the internet to the citizens of RT. 36, they could finally get used to operating it. The trainings were quite successful in giving knowledge and insight to the citizens about the function of the internet. Then, every house is supplied with a laptop or a computer in the village to access the internet.

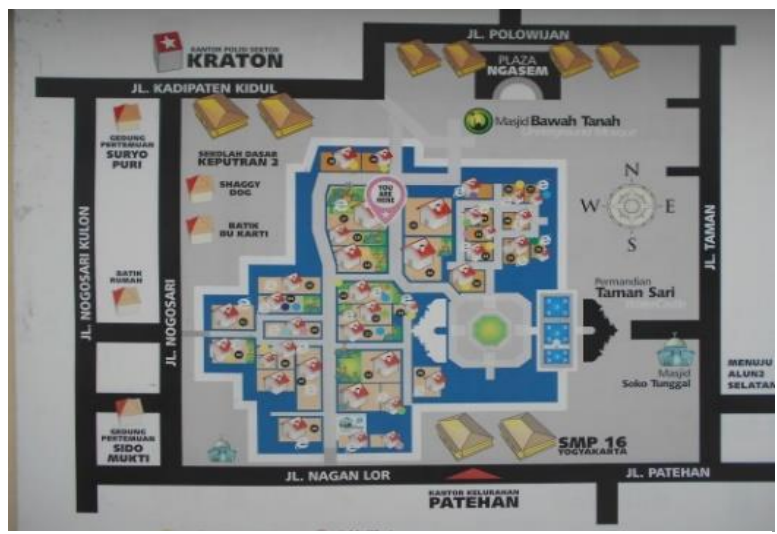

Fig. 10. The Map of Village Cyber along with information on houses connected to the internet. (Source: Personal Documentation; 9/3/2016; 10.30) 
The success to spread internet literacy among the citizens of RT 36 has supported the village to be a socio-laboratory; hence, many tourists are coming either individually or in groups (school or university students) from both regional and international institutions to examine more deeply regarding internet-based identity in this village. Tourism from the socio laboratory activities enables the Cyber Village to become persistenly settled, as seen from the provision of the pretty decent media accomodating either small or big discussions.
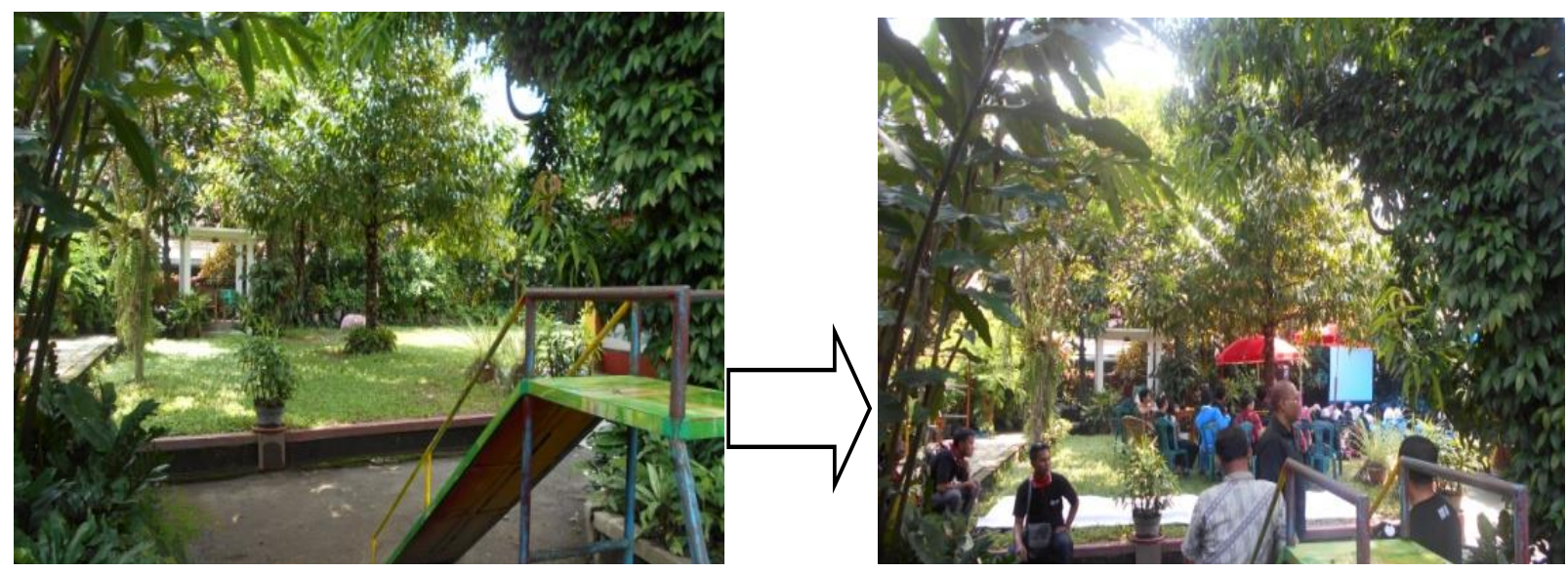

Fig. 11. One of the open lands belonging to a resident that is used as gathering space between residents and tourists; it acts as a socio-laboratory for school or university students (Source: Personal Documentation; 9/3/2016; 10.30).

\section{Distribution of communal space as a gathering point}

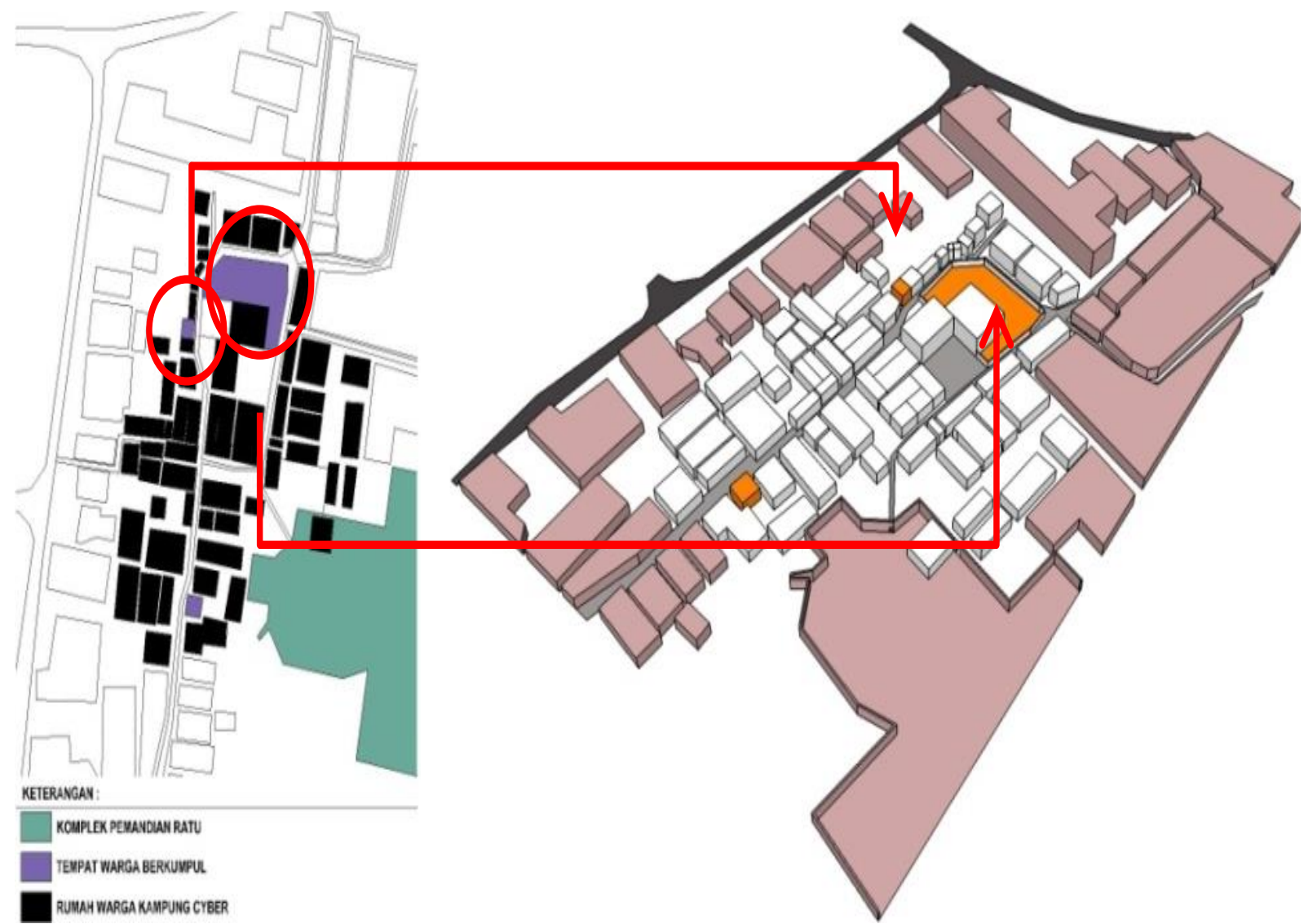

Fig. 12. The mapping of current communal space distribution in the Cyber Village. (Source: Personal Documentation; 9/3/2016; 10.30). 


\section{Distribution of Tourism Activities}
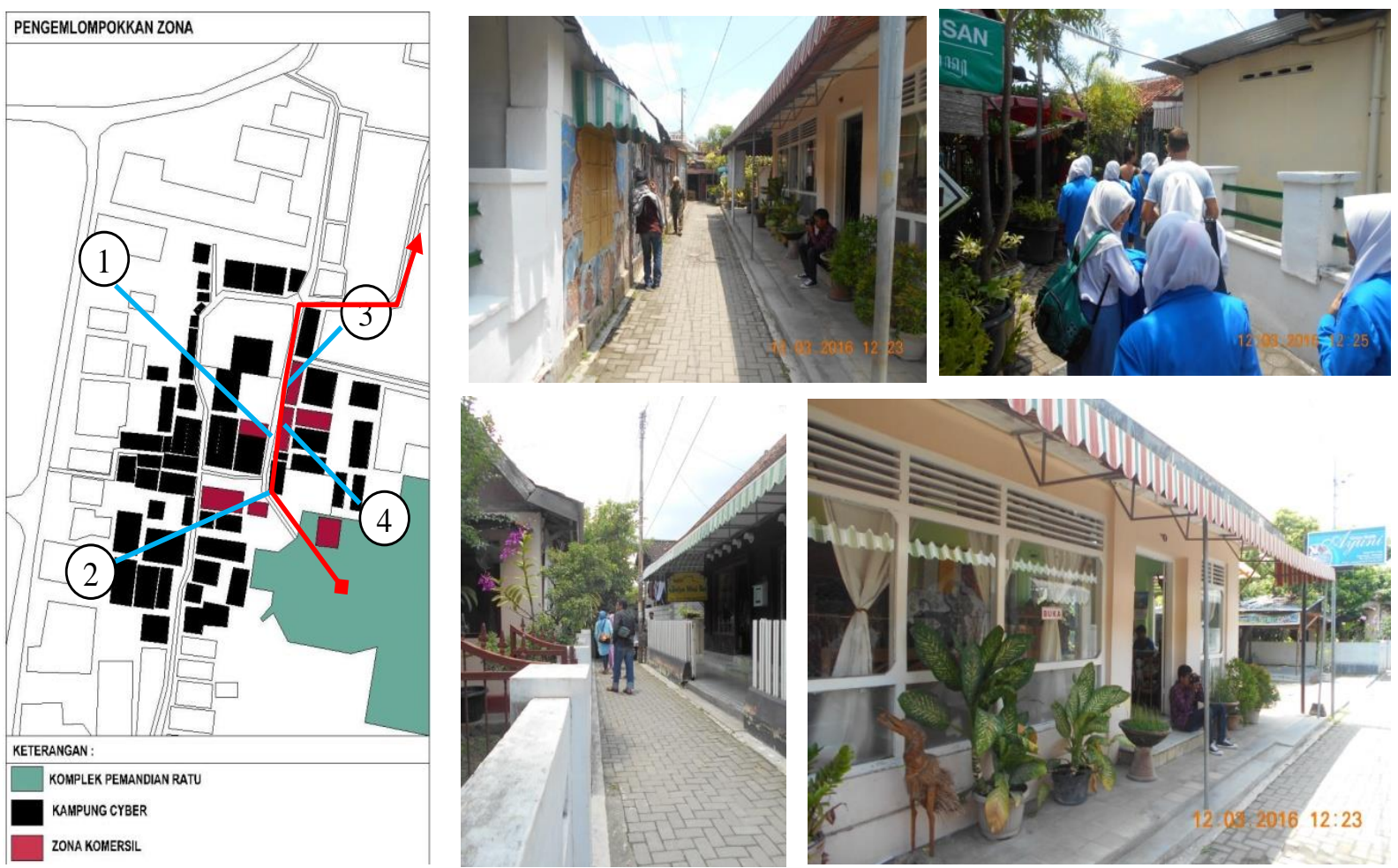

Fig. 13. The location of kiosks in Cyber Village in the alleys inside Tamansari complex (Source: Personal documentation; 9/3/2016; 10.30)

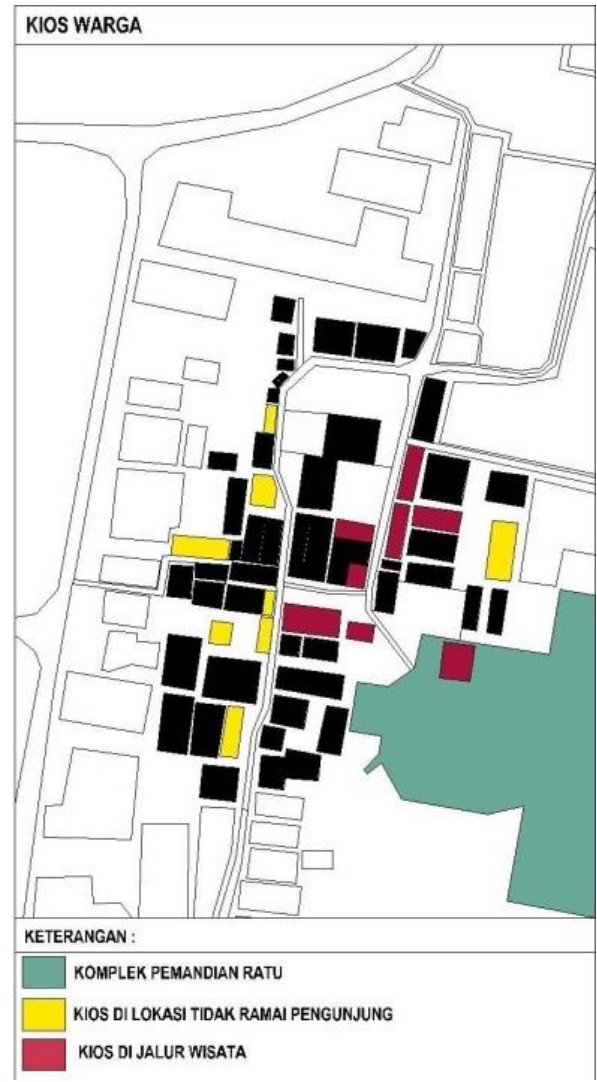

Fig. 14. The mapping of the location of brisks (Source: Personal Documentation). 
Analysis of behavior setting towards the neighborhood

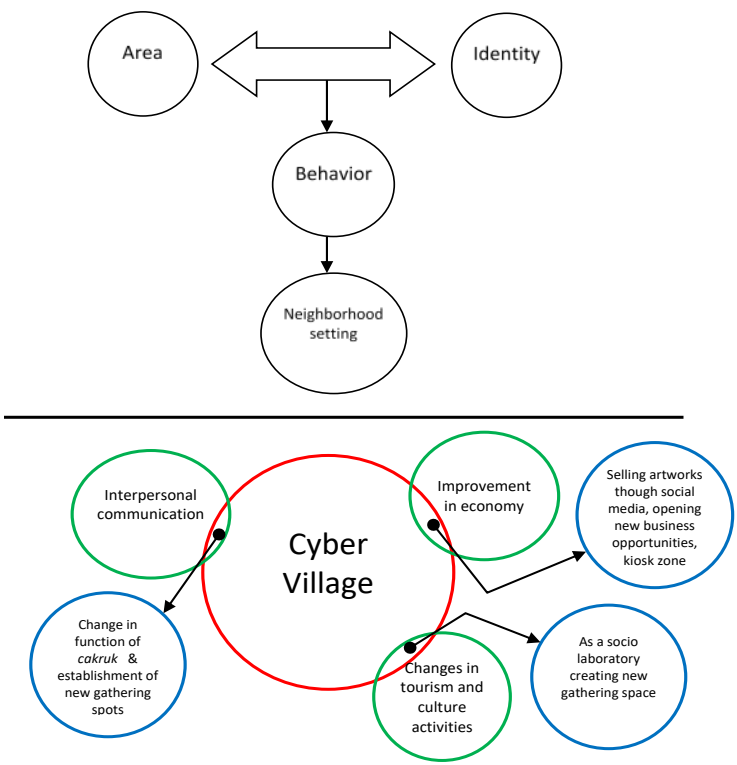

Fig. 15. The pattern of relations in the change of identity of RT 36 into a Cyber Village (Source: Personal Documentation).

\section{Aspects of Behavior Settings}

Important features of behavior settings are categorized into three aspects: source, internal dynamics, and context. Furthermore, behavior settings can be seen in relation to their earthly stages. Setting resources including people, objects, behaviors, physical space, and information have access settings. The quantity and quality of these resources are both concerned. In a broader context, the resources are also important influences on behavior settings. Meanwhile, internal dynamics include personal cognition and motives, functional activities, social process, growth, and stability. Contextual characteristics involve political, law and economic conditions; historical settings; and the relationship between these settings and other settings, or greater organizational or social units (Luke, Rappaport, \& Seidman, 1991)

\section{Resources}

RT 36 Tamansari has set information technology, in particular the internet, as their identity. One of the diverse benefits from the development of information and communication technology (ICT) is to improve the quality of human life. Improving the quality of human life means the demand to perform various activities by optimizing our own resources where distance will no longer be a distraction. Information and communication technology has advanced quickly, yet urge people to utilize it in all activities (Rasmaya \& Sutriadi, 1982). The other advantage of internet for RT 36, in addition to giving identity, is to help optimize the social, economic, tourism and culture potentials. It is seen that the internet is a form of resource that affects the citizens' behavior and push them to create physical space that suits their needs.

\section{Internal Dynamics}

Information technology namely the internet gives impact to the internal dynamics of behavior, namely cognitive patterns of the citizens. The coming of internet to the village can facilitate communication without time boundaries. Such condition forms a new social pattern between the residents, making them steadily attached to information technology in the daily life, both in social communication, economic, tourism and cultural activities.

\section{Contexts}

Behaviors always occur somewhere, in some context (Heft, Hoch, Edmunds, \& Weeks, 2014). Contextually, information technology influences the flow of social, economic, tourism and cultural activites which have long been existing in RT 36. Information technology is able to change daily activities in RT 36 into a tourist attraction. From a social viewpoint, the residents will gather on a regular basis with prior notifications through social media. All forms and channels of information, including extension, counselling, community works, and so on are all announced through social media or sms gateaway, thus no need to distribute letters of invitations to distribute information. From the economic aspect, the community of cyber village can sell their products directly or post them through social media. Thanks to the internet, a number of artists could introduce their artworks through social media and making them more widely recognized. From the tourism viewpoint, the development of the internet contributes to the reputation of the village as a socio laboratory for people both locally and from abroad who want to learn the Cyber Village. From the aspect of socio-culture, the internet provides convenience to promote the village and all of locally manufactured products, such as batik handicrafts, statues, t-shirts, and shadow puppets. Many of the craftsmen who were initially unproductive can now feel the benefits of internet to improve their creativity.

\section{CONCLUSION}

Changes in the image of RT 36 Tamansari into a "Cyber" village support the existence of information technology as a new identity which then influences 
the individual behavior as seen from the social, economic, tourism and culture aspects. In the end, it gradually affects the settings of the physical space of the village. This change in behavior is reinforced by 3 aspects of behavior settings: sources, contexts and internal dynamics. These three aspects indicate identity changes, leading to changes in behavior patterns. Finally, there has been growing physical space that adapts to the needs of the citizens' behavior.

\section{Socio-economic aspects}

1. With the rising of internet in the village, there is a need for a server room. Cakruk which used to be a security post and citizen information center in RT 36 turns into the main server room. The shift in the function of cakruk encourages the citizens to set up a new gathering spot.

2. Internet makes it easy for citizens to communicate with each other, so that in the economic viewpoint, it is very helpful to improve community's welfare. Information technology enables the citizens to stimulate their creativity by setting up business outlets, despite the unstrategic location (not near the street). In fact, the business is brisk, though the communication simply runs through social media.

\section{Tourism, Art, and Culture Aspects}

RT 36 belonging to Tamansari complex is a culture village which is recognized with its Batik craft. The internet, in addition to introducing art and culture in this cyber village, has attracted the tourists to learn more on the neighborhood. Furthermore, the village has changed into the socio-laboratory for domestic and foreign tourists so as to maintain the reputation of RT 36 as a cyber village. Moreover, some open space belonging to residents are transformed into spots for either small or big discussions.

\section{ACKNOWLEDGMENT}

I am deeply indebted to my supervisor, Dr. Amos Setiadi, S.T., MT, for warm support, inspiration and thoughtful guidance.

\section{REFERENCES}

Barker, R. (1987). Prospecting in environmental psychology (In D. Stocols \& I. Altman (Eds.), Handbook of environmental psychology ed.). New York: John Wiley and Sons.

Google earth.com. (2016, August 21).

Hakim, B. R. (2016). Logbook Penelitian Penerapan Citra Visual sebagai pembentuk "Public Image". Yogyakarta.

Heft, H., Hoch, J., Edmunds, T., \& Weeks, J. (2014). Can the Identity of a Behavior Setting Be Perceived Through Patterns of Joint Action? An Investigation of Place Perception. Behavioral Sciences, 4(4), 371-393. http://doi.org/10.3390/ bs 4040371

John, N. (2004). Psikologi Lingkungan. Bandung: Andira.

Lang, J. (1987). Creating Architectural Theory. New York: Van Nostrand Reinhold Company.

Luke, D. A., Rappaport, J., \& Seidman, E. (1991). Setting phenotypes in a mutual help organization: Expanding behavior setting theory. American Journal of Community Psychology , 19(1), 147-167.

Popov, L., \& Chompalov, I. (2012). Crossing Over: The Interdisciplinary Meaning of Behavior Setting Theory. International Journal of Humanities and Social Science, 2(19), 18-27.

Prasetyo, A. G. (2014). Domestikasi Teknologi Internet: Studi Di “Kampoeng Cyber” Rt 36 Taman, Yogyakarta. Universitas Gadjah Mada.

Rasmaya, A., \& Sutriadi, R. (1982). Peran Teknologi Informasi dan Komunikasi Dalam Mendukung Kegiatan Bekerja dan Konsumsi Fasilitas Pemilik Perumahan Formal di Kecamatan Jatinangor. Jurnal Perencanaan Wilayah Dan Kota 2 SAPPK V3N3, (1), 421-429.

Samatan, N., \& Sutanlo, L. (2013). Signifikansi Media Baru Dalam Meningkatkan Intensitas Komunikasi Interpersonal Terhadap Solidaritas Sosial Di Kampung Cyber Yogyakarta. UG Jurnal, 7(8), 1-5.

Sasongko, A. (2016, Maret 9). Identitas Kampung Cyber. (B. R. Hakim, Interviewer). 